\title{
The Constitutional Policy:
}

\author{
State Recognition of the Believers in Indonesia
}

\author{
Ahmad Tholabi Kharlie \\ Syarif Hidayatullah \\ State Islamic University Jakarta, Indonesia \\ abimania@yahoo.com
}

\author{
Fathudin \\ Syarif Hidayatullah \\ State Islamic University Jakarta, Indonesia
}

\begin{abstract}
The policy of unfilled the religion column as listed in the Identity Card for the believers (spiritual group) leads into the neglected citizenship rights to access the various public services such as education, health, occupation, and others. The constitutions of citizenship administration which have been regarded as the main factor of discrimination problem are tested on its degree by the Constitutional Court of Indonesia through a petition for judicial review which is proposed by the believers (spiritual group). As a response to their petition, the Constitutional Court gives an approval to Indonesian believers' existence to belief in one God Almighty through its decision No. 97/PUU-XIV/2016. The impact of its decision at this time is that the believers' community can fill their religion in the column of Identity Card (KTP). This article aims to analyze a legal consideration of the Constitutional Court of the Republic of Indonesia on its decision No. 97/PUU-XIV/2016. The result shows that the Constitutional Court of Indonesia has made an extensive interpretation on the meaning of 'religion' and 'belief'; hence the believers can put their faith/belief in Identity Card (KTP).
\end{abstract}

Keywords - The Believers; Constitutional Right; Population identity; religion column; Identity Card;

\section{INTRODUCTION}

As a country with more than 250 million of the population, Indonesia is inhabited by various ethnic groups. They are 1.340 ethnic groups with their cultural styles. In spite of that, the plurality of Indonesia is seen from many religions and beliefs adhered by its citizen. According to the Ministry of Education and Culture 2017, there are six religions recognized by Indonesian government (Islam, Christian, Catholic, Hindu, Buddha, and Confucianism), 187 of organization groups, and 12 million of the believers (spiritual group) who have been spread over Indonesia. Thus, the reality of various sociocultural makes Indonesia as a nation with a high degree of diversity.

In spite of the believers (spiritual group) have been existed for a very long time before Indonesia was formed, their existence are lacks of an equal space compared to the six official religions which are recognized by the government. Although the faith or beliefs in spiritual God is regarded as not religion or new religion, their existence basically are the inheritance and spiritual wealth of the Indonesian and its adherents are called as penghayat (believer in one God) and pengamal kebudayaan bangsa (cultural doer)

The religion term was newly carried out in Indonesia in 1961 by the Ministry of Religious Affairs. At that time, the narrow term of religion was defined by the government and it became an official definition that was used up to now (Mulder, 1983:5). The policy was created based on the increasing number of spiritual groups. In 1953 there were more 360 of spiritual groups spread all over Java. These groups play their role in general election in 1955. Thus, Islam parties failed to win a majority vote and only got 42 percent of the vote (Taher, 2009: 379-380).

The policy was followed by the enactment of Indonesian president No. 1//PNPS 1965 about the prevention of manipulation or defamation on the religions which differentiates in two categories. The first, six religions which are adhered by the majority of Indonesian are Islam, Christian, Catholic, Hindu, Buddha, and Confucianism. The second, other religions are allowed by the government such as Jews, Zarasustrian, Shinto, and Taoism. They get full legal protection as stated in Article 29 Verse (2) of the 1945 Constitution. Their existence is permitted as long as they do not violate the provisions which contained in the constitution. While, the government tries to transfer the stream/spiritual group into a positive view and bring their beliefs in one Almighty God. That is in accordance with MPRS No. II/MPRS/1960.

In the reality of its development, Indonesian believers (spiritual group) deal with many discrimination problems and much harshness. The National Commission on Violence against Women (2016:6) record states that 115 cases of the harshness and discriminations occurred in 2011-2015. There are found 65 discrimination cases from 115 cases during the monitoring of 10 communities of the believers (spiritual group), the believers in ancestral spirit, and the practice of custom ritual in 9 provinces. Meanwhile, half of the 65 discrimination cases are abandonment cases when applying for the population administration. Those kinds of discrimination are the problem in applying for the population administration in form of personal documents such as the trouble of having Indonesian Identity Card, Birth and Marriage Certificate. There are many regulations to differentiate the citizen right in accessing population identity services based on their religion 
or the citizen's faith as stated in the constitution Number 24 Year 2013 concerning on the change of constitution in number 23 Year 2006 concerning on the population administration and the government regulation, number 37 Year 2007 concerning on the implementation of the citizenship constitution.

Although the believers' communities are still served to access the population identity services, the policy of emptying the religion column as stated in the population administration constitutions gave birth to serious problems. The constitutional rights of the believers are neglected by the government. In fact, this problem creates more complicated problems for them and their descendants to access other basic services which are provided by the Government.

New decision of the Constitutional Court of the Republic of Indonesia Number 97/ PUU-XIV/2016 becomes a new hope for the existence of the believers' community in Indonesia. Based on that decision, the believers community can fill their faith of identity in the religion column listed in the Identity Card (KTP). This policy certainly bring about a solution in the midst of various discrimination in Indonesia that occurred for many years. This article aims to explain the efforts of the state that expressly acknowledge the existence of believers (spiritual group) through the decision of the Constitutional Court of the Republic of Indonesia Number 97/ PUU-XIV/2016.

\section{The RELigion And StATE RELATION}

Since the beginning of Indonesian independence until now, the relationship between state and religion have become an endless debate. On the one hand, Indonesia is a country that guarantees its citizens freedom to adhere their beliefs/faith. On the other hand, the state has a strong intervention to determine what religion is worthy of being adopted by its citizens. That's why Julia D. Howell calls this as 'limited pluralism' refering to the type of a freedom practiced in Indonesia (Muhammadiyah, 2015: 98). In Article 29 of the 1945 Constitution of the Republic of Indonesia states that Indonesia is a country bases on a belief in One Almighty God and guarantees the independence of every citizen to adhere his or her own religion and to worship according to his/her religion and belief. The word 'belief' in this chapter refers to belief in one Almighty God that proposed by Mr. Wongsonegoro in the BPUKPI session (Maskur, 2012:4). The editors of the constitution provide assertion that Indonesia is not a secular state and not also called as a religious state. The consciousness that God is existed in the history of Indonesian national development implies a psychiatric attitude in contrast to the development of nationalism in Europe. In European countries, the rise of nationalism (secular) coincided with the fading of religious influence. This history is different from Asia, when nationalism moves, religious issues are also moving forward (Latif, 2012: 55-56).

As a concrete realization form of constitutional paradigm, Indonesia should have a role and duty in giving protection to religious life either in the form of constitutional recognition and protection or other applicative policies that embody the principles of religious freedom as it was adopted by the constitution. According to Yudi Latif, religious life with the willingness to accept diversity has been accepted for a long time as fairness by the people in the history of Indonesia. Since the time of the Majapahit empire, the doctrine of civil religion to accept the diversity of religious expression has been formulated by Empu Tantular in Sutasoma's book, "Bhineka Tunggal Ika tan Hana Dharma Mangrwa", it means unity in diversity, no ambiguous truth (Yudi Latif, 2012: 56) .

The constitution's affirmation as stipulated in the 1945 Constitution of Number 29 can also be interpreted that Indonesia as a country with its pluralism chooses the paradigm of symbiotic relationship between the religion and state. This paradigm was born as a result of the classical debate on the formula of relations between religion and the state including the relation of the concrete foundation of religious values in a state life. The debate on the idea of religion and state relations creates three paradigms beginning from the integralistic (unity of state and religion), secular paradigm (the state should not establish, or fund, religious activities), and symbiotic (mutual cooperation) (Hosen, 2005: 421-422). Although Indonesia is not a religious country, Indonesia is not a secular country either. Moh. Mahfud MD calls this understanding by the concept of Pancasila, ideology, and the prismatically national state (Moh Mahfud MD, 1999: 55). The prismatic concept politically is a logical option than other sectarian, as the result of a long debate on the relationship of religion and the state that took place not only during the formation of the 1945 Constitution but also since the 1940s. Even in the period of reform in 1999, the issues of religion and state relations have also emerged as a political issue both formal and informal sector (Moh Mahfud MD, 1999: 55).

State recognition and protection on all religious entities and beliefs affirm that Indonesia is a constitutional state. In this case, the constitutional state means a legal state bases on the recht idee which contains understanding of the recognition on a principle of law supremacy and constitution, and human rights guarantees (Dicey, 1971: 223-224). In Abdullahi Ahmed An-Na'im's view (1996), the recognition and protection provided by the state for those rights and the meets for its constitutional standard were affirmed by Indonesia. AnNa'im's view on constitutionalism is defined as the availability of a legal and political framework by the state to realize and protect the equal status, human rights, and welfare of all citizens (An-Na'im, 2007: 145). As one of the constitutional principles is emphasized on the moral justification of the equal principle with the assumption that all cultural and religious traditions generally teach that, one should treat well others as he or she wishes to be treated well by others (An-Na'im, in Ahmad Suaedy, 2007: 122- 123).

Indonesian Constitution in Article 28E Paragraph (1) of the 1945 Constitution of the Republic of Indonesia affirms that everybody has the right to freedom to embrace a religion and worships according to his/her religion, to have education and teaching, to get the occupation, to choose the citizenship, to change a residence in the territory of the state, and to be registered when he/she chooses to return to his/her country. Then in verse (2) is also affirmed that everyone has the right to freedom to believe in, to express thoughts and attitudes in accordance with his/her conscience. The article actually 
provides the affirmation of an equal position for the believers (spiritual group) and the adherents of other religion. Both of them have a belief system. Whether the believer (spiritual group) or the adherents of other religion are an expressions of a transcendent belief. In fact, the religious adherents and believers have the same sense of longing for an inner power. In the perspective of human rights, the existence of the spiritual group is also guaranteed as stated in article 18 Universal Declaration of Human Rights, which was born on December 10, 1948:

Everyone has the right to freedom of thought, conscience and religion;the right includes freedom to change his religion or belief, and freedom, either alone or in community with others and in public or private, to manifest his religion or belief in teaching, practice, worship and observance.

Although the Indonesian Constitution provides an equal recognition between religion and belief, in other provisions such as MPR Decree Number IV/MPR/1978 on GBHN chapter IV no 13 number 1 letter $F$, the spiritual group is defined as a belief in God Almighty and the religion is imported outside other religion which are recognized by the state. Then the spiritual group is not a new religion but a national culture. While religious beliefs (faith) and a belief based on creation, inventiveness, taste of human initiative is called as a spiritual group. At that time, MPR Decree was responded by the Minister of Religious Affairs with the instruction of the Minister of Religious Affairs No. 4 of 1978 Concerning on the policy of the spiritual group. In this instruction, the Ministry of Religious Affairs no longer takes care of the issue of spiritual group because it refers to the provisions that contained in the MPR Decree. These provisions are reinforced by the provisions that contained in the Presidential Decision of the Republic of Indonesia Number 1/PNPS of 1965 concerning on the prevention of the manipulation or blasphemy which is regarded as the basis of the legitimacy of state recognition for the six religions such as Islam, Christianity, Catholic, Hindu, Buddhist and Confucianism. This provision brings about the concept of the official religion and non-official religion. The six mentioned religions are regarded as the official religions, while the spiritual group is recognized by the state but not referred to as the official religion.

The affirmation of the existence and position of the spiritual group in Indonesia was conveyed by President Soeharto during his speech to the House of Representatives on August 19, 1978. He says that the belief in God Almighty is part of the Indonesian National Culture. In his speech President Soeharto stated,

Belief in one God Almighty (spiritual group) is neither a religion nor a new religion. It is not necessary to be compared and contrasted with other religion (the official religion). Belief in God Almighty is a cultural reality that lives and it is respected/adhered by some of our people. Belief in God Almighty basically is the inheritance and spiritual wealth of our people. We can not just deny it ... As part of the cultural heritage, the civilizing of the belief in God Almighty will be placed within the Ministry of Education and Culture ... (Tjokrowisastro, 1985: 316).

\section{Discrimination Problems of The Believers IN ONE GOD}

Indonesian government defines the spiritual group not as a religion but as part of Indonesian cultural heritage. According to the government's assumption, the believers in one God (the spiritual group) are still embrace one of the recognized religions in Indonesia besides their beliefs. In the Circular Letter of the Minister of Religious Affairs No. B.VI / $1121 \mathrm{~S} / 78$ asserts that religious people who follow spiritual group do not lose their official religion. In fact, there is no marriage and oath procedure in the spiritual group. Then the problem arises when the couple who adhere the spiritual group need to register their marriage. They can't register it because the spiritual group marriage is not known historically and juridically and automaticly the marriage record of the believers is also not known (Susetyo, 1998: 157).

Discrimination problem which is experienced by the believers in Indonesia is also rooted in the degree of constitutional Number 24 Year 2013 regarding on the Amendment of the Constitution Number 23 Year 2006 concerning on the Population Administration. In that Constitution there is a policy of emptying the religion column listed on ID card (the population identity) particularly for the believers (spiritual group). This case certainly affects the impairment of other constitutional rights, especially in access to public services. Because the religion columns on their Identity Card are empty, they face various discrimination problems ranging from customary marriages which are not recognized by the state to the difficulty in obtaining a marriage certificate. As a result, their children also find difficulties to get birth certificate and jobs services, even if they have good competence. Some of them also have the same experience which causes the funeral of their family members is refused to be buried in the public cemetery. Other basic rights such as the right to have education, to get the occupation, to get health, to have social security and all services also face the same problem. In the more extreme condition, emptying the religion columns on Identity Card (KTP) often makes them to be stigmatized as atheists, excommunist (PKI) and heretical sects. Therefore they become social vulnerable groups with various acts of discrimination, intolerance, and violence.

Article 61 Paragraph (1) of the Citizenship Administration Constitution states that the Family Card (KK) contains information in its column such as full name of the head of household and family members, ID Number For the Population (NIK), sex, address, place of birth, date of birth, religion, education, employment, marital status, family relations status, citizenship, immigration documents and parents' names. While in paragraph (2) it is mentioned that the description of the religion column as referred to in paragraph (1) for the citizen whose religion/belief has not been recognized as the official religion in accordance with the provisions of the constitution shouldn't be filled in its column, 
but they are still served and recorded by the government in the population database. The same thing is also found in Article 64 paragraph (1) which states that Electronic ID Card (KTPel) includes the symbol image of Pancasila and map of the territory of the Unitary State of the Republic of Indonesia also contains some elements of population data such as ID Number for Population (NIK), name, place of birth date, male or female, religion, marital status, blood type, address, occupation, nationality, photo, validity period, place and date issued ID card, and the owner signature of ID card. Article 64 paragraph (5) states that the element of religious resident data as referred to in paragraph (1) for the citizen whose religion/belief has not been recognized as an official religion based on the provisions of the constitution shouldn't be filled in its column, but they are still served and recorded in the population database.

The provisions in the Population Administration Constitution are inadequate in giving the protection and fulfillment of the equal rights for the believers as the Indonesian citizens. The believers such as Batak Parmalim, Marapu, Sunda Wiwitan (Sunda Java Believe), Sapto Darmo, and others have discrimination in accessing public services because the religious columns listed on ID cards and Family Cards were emptied. Even, the Identity Card is being emptied, they are often stigmatized as atheists, ex-communist (PKI). They feel difficult to get an equal access in public services which were provided by the government.

Discrimination problem that experienced by the believers community becomes the main reason for a number of the believers in several regions in Indonesia to submit a petition for judicial review of Article 61 paragraph (1) and (2), Article 64 paragraph (1) and (5) of constitution Number 23 Year 2006 regarding on the Population Administration Constitution, No. 24 of 2013 on Amendment of constitution Number 23 Year 2006 concerning on the Population Administration (Population Administration Constitution) to the Constitutional Court of the Republic of Indonesia.

Their petition for the Constitutional Court of the Republic of Indonesia bases on a number of reasons as follows (Summary of Petition of Case Number 97 / PUU-XIV / 2016, 2017: 4-5). Firstly, Article 61 Paragraphs (1) and (2), Article 64 Paragraphs (1) and (5) of the Population Administration Constitution are contradictory to the principle of state constitution and the citizens equality in front of the law, because in its formulation is written that the Family Card (KK) and ID Card (KTP) contains elements of religion information in its column but the believers prosecuted to empty their religion in the information column, so that is contradictory to Article 1 paragraph (3), Article 27 paragraph (1), and Article 28D paragraph (1) of the 1945 Constitution. Secondly, that Articles are not clearly and logically instructed, so that laws bring a different interpretations and violate the basic rights of citizens. Thirdly, the provision of emptying the religion column for believers has violated the fundamental rights of the believers. Fourthly, the emptying of religious columns on ID cards causes the believers in Indonesia unable to access and obtain other basic rights such as the right to have education, to get work, to get health, to have social security and all services. Thereby that article violates human right and the 1945 of Indonesian Constitution. Fifthly, 61 Paragraphs (1) and (2), Article 64 Paragraphs (1) and (5) of the Population Administration Constitution have made the exclusion for the believers. The petitioners with the non-filling of the religion columns in the Family Card (KK) and ID Card (KTP-el) leads to discrimination. Therefore the petitioners have been subjected to many violations of constitutional rights, so that those articles are contradictory to Article 28I Paragraph (2) of the 1945 Constitution.

In the request of the Judicial Review on the Population Administration Constitution, the petitioners ask to the Constitutional Court of the Republic of Indonesia to declare on; firstly, that Article 61 Paragraph (1) and Article 64 Paragraph (1) of the Population Administration Constitution are contradictory to the 1945 Constitution and have no conditionally constitutional as long as the term of the believer in one God (spiritual group) and other religions are not be inclusively interpreted and added in the term of religion. Secondly, Article 61 Paragraph (2) and Article 64 Paragraph (5) of the Population Administration Constitution are contradictory to the 1945 Constitution No (3) Article 61 Paragraphs (2) and Article 64 Paragraph (5) of the Population Administration Constitution have no conditionally constitutional with all consequences (Summary of Petition of Case Number 97 / PUU-XIV / 2016, 2017: 6).

\section{Progressive Decision of the Constitutional Court of THE REPUBLIC OF INDONESIA}

The Decision of the Constitutional Court of the Republic of Indonesia Number 97/PUU-XIV/ 2016 brings a new hope for the existence of the believers in Indonesia. The decision of the Constitutional Court is a step forward to end discrimination problem of the citizenship administration that has been experienced by the believers. In its ruling, the Constitutional Court of the Republic of Indonesia accepts all the the believer's petition. The Constitutional Court declares that the word 'religion' in Article 61 paragraph (1) and Article 64 paragraph (1) of Constitution Number 23 Year 2006 concerning on the Population Administration as amended and changed by the Constitution Number 24 Year 2013 regarding on the Amendment of Constitution of Number 23 of 2006 concerning on the Population Administration are contradictory to the 1945 Constitution of the State of the Republic of Indonesia and it does not have conditionally constitutional as long as it does not include the term of 'belief'. In addition, according to the Constitutional Court, Article 61 Paragraph (2) and Article 64 Paragraph (5) of the Population Administration Constitution are also contradictory to the 1945 Constitution of the State of the Republic of Indonesia and have no conditionally constitutional (Copy of Decision of the Constitutional Court of the Republic of Indonesia Number 97 / PUU-XIV / 2016: 154).

According to the Constitutional Court, the right to adhere the religion and belief in God Almighty is one of the rights of the civil and political groups derived from the concept of natural rights. As the origin of the right comes from natural right, this right is inherent in everyone because he/she 
basically is a human being and not a state. In the context of Indonesia, this statement is no longer merely something of doctrinary value but has become the norm in the constitution. Then it binds all branches (governments) and its citizen as it is set out normatively in Article 28E paragraph (1) and paragraph (2) and Article 29 paragraph (2) of the 1945 Constitution. (Copy of Decision of the Constitutional Court of the Republic of Indonesia Number 97 / PUU-XIV / 2016: 138). State recognition on the right to adhere a religion and belief is not a gift from the state. It shows that there is the affirmation on the concept of universal human rights which has been adopted by Indonesia. As Jack Donnelly calls human rights as the universal rights. It is not gains, responsibilities, privileges, or some other form of giving but given as a result of one's human dignity (Donnelly 1982: 304).

According to the Court, the right or freedom to adhere a religion (including the believers/spiritual group) is an inherent right of everyone because it is derived from the group of natural rights, not given by the state. Therefore, the religious and the believers rights to believe in are one of human rights. As a legal state that requires one of the protection on human rights, it brings the consequences of the state's responsibility to ensure that the rights of its citizens are fulfilled in the reality of daily practice (Copy of Decision of Constitutional Court of the Republic of Indonesia Number 97/PUU-XIV / 2016: 149-150). If it is placed in a more universal context, the recognition of religious rights and the belief in the Almighty God as mentioned in the Indonesian Constitution will also correspond to the spirit of the formulation of religious freedom as stated in the Universal Declaration of Human Rights (DUHAM) and the International Covenant on Civil and Political Rights (ICCPR) which has been ratified by Law Number 12 Year 2005 on the Ratification of the International Covenant on Civil and Political Rights (ICCPR).

According to the Constitutional Court, Article 61 Paragraph (1) and Paragraph (2) and Article 64 Paragraph (1) and Paragraph (5) of the Population Administration Constitution hold the view that the intended religion here is the recognized religion (the six religion officially) in accordance with the Constitution. It means the citizen right to get freedom in following their religion is restricted on the recognized religion only (the six religion officially) and based on Indonesian Constitution and regulations. Consequently in a contrario, the constitutional responsibility or the state's obligation to guarantee and protect the citizen's right to adhere their religion (which actually includes belief in God Almighty) is also limited to those citizens who adhere an official religions as the recognized religion in the provisions of the constitutional. So that article is not an accordance with the spirit of the 1945 Constitution which explicitly ensures that every citizen is free to adhere the religion and belief and to worship based on their religion and belief (Copy of Decision of the Constitutional Court of the Republic of Indonesia Number 97 /PUU-XIV / 2016:149). The original meaning of 'religion' in the constitution is a religion in the sense of being recognized as an official religion based on the provisions of the Constitution and regulations then its regulation will deny the believers in getting the recognition, guarantee, protection, and equal law, moreover equal treatment in front of the law.
Recognition of their existence in the ID Card column is impossible to obtain because the term of belief in one God is not mentioned in Indonesian Constitution (Copy of Decision of the Constitutional Court of the Republic of Indonesia Number 97 / PUU-XIV / 2016: 151).

In the verdict of the Constitutional Court of Justice stated that the status of the believer can be registered in the religious column on the Family Card and the Electronic Identity Card without the need to specify the spiritual group. According to the Constitutional Court, the differences in the arrangements of applying the population data element among citizens are not based on constitutional reasons but such arrangements have treated both of them differently under legislation in accessing public services. Therefore, the Constitutional Court confirms that the word 'religion' in Article 61 Paragraph (1) and Article 64 Paragraph (1) of the Population Administration Constitution is contradictory to the 1945 Constitution and does not have a conditionally constitution as long as it does not mention the believers term (Copy of Decision of the Constitutional Court Republic of Indonesia Number 97/ PUUXIV / 2016: 153)

The Constitutional Court and the 1945 Constitution stated that the idea of a democratic state is that the state is established and built to protect those rights (which also means to respect and to guarantee all citizens need). The Population Administration Constitution limits the citizens right to adhere religion only to the official religion. Consequently, in a contrario, the state's responsibility to guarantee the religion right is also limited to those who profess the recognized religion (an official religion). This is not an accordance with the spirit of the 1945 Constitution which explicitly ensures that every citizen is free to adhere religion and belief and to worship according to their religion and belief.

\section{CONCLUSION}

The extensive constitutional interpretation conducted by the Constitutional Court of the Republic of Indonesia in Article 61 Paragraph (1) and (2) of the Citizenship Administration Constitution is a progressive interpretation. The term 'religion' in the constitution is considered unconstitutional as long as the term of spiritual group is not interpreted in the constitution. This verdict certainly effects the existence of the believers particularly to gain the States recognition. The discrimination of the population administration that has been experienced by the believers are increasingly finds a solution. Once the religion column are listed in their Identity Card, the stigma of atheist and the excommunist (ex-PKI) attached to them are soon disappeared. Moreover, they have the equal rights with other adherents to access any public services. 


\section{REFERENCES}

[1] Niels Mulder, Kebatinan dan Hidup Sehari-hari Orang Jawa: Kelangsungan dan Perubahan Kultural (Jakarta: Gramedia, 1983)

[2] Nadirsyah Hosen, "Religion and Indonesian constitution: A recent Debate" Journal of Southeast Asian Studies / Volume 36 / Issue 03 October 2005.

[3] Jack Donnelly, "Human Right and Human Dignity: An Anallytic Critique of Non-Western Conceptions of Human Right", The American Political ScienceReview, Vol. 76, No. 2., https://www.jstor.org/stable/pdf/1961111.pdf

[4] Trisno, S. Sutanto, "Politik Kesetaraan" dalam Dalam Elza Peldi Taher (ed.), Merayakan Kebebasan Beragama: Bunga Rampai Menyambut 70 Tahun Djohan Effendi, (Jakarta: ICRP-Kompas, 2009)

[5] Ali Maskur, "Membaca Ulang Eksistensi Aliran Kepercayaan di Indonesia" dalam PUSHAM UII, Membaca Kasus-Kasus Aktual tentang Hak Asasi Manusia, (Yogyakarta: PUSHAM UII, 2012)

[6] Yudi Latif, Negara Paripurna;Historisitas, Rasionalitas dan Aktualitas Pancasila, (Jakarta: PT. Gramedia Pustaka Utama, 2012)

[7] Hilmi Muhammadiyah, "The Relation between Religion and State in Indonesia" Asian Social Science; Vol. 11, No. 28; 2015

[8] A.V. Dicey, An Introduction to Study of the Law of the Constitution, 10th edition, (London: English Language Book Society and MacMillan, 1971)
[9] Abdullahi Amhed An-Na'im, Toward an Islamic Reformation ; Civil Liberties, Human Right, and International Law, Terj. Ahmad Suaedy, Dekonstruksi Syariah; Wacana Kebebasan Sipil, Hak Asasi Manusia, Hubungan Internasional dalam Islam)

[10] Abdullahi Ahmed An-Na'im, Islam dan Negara Sekuler; Menegosiasikan Masa Depan Syariah, (Jakarta : PT. Mizan Pustaka, 2007)

[11] David. R. Williams, World Religion and The Hope For Peace, (Boston: Beacon Press, 1951),

[12] Soedjito Tjokrowisastro, Pedoman Penyelengqraan Catalan Sipil (Jakarta : Bina Aksara, 1985)

[13] Heru Susetyo, "Pencatatan Perkawinan Bagi Golongan Penghayat" Jurnal Hukum dan Pembangunan Vol 28 1-3 Tahun 1998, h. 157

[14] President's decision Number 1/PNPS Year 1965 on Prevention of manipulation or Blasphemy.

[15] National Commission on Violence against Women of the Republic of Indonesia (Komnas Perempuan), "Independent Report on Universal Periodic Review (UPR) of 2016"

[16] Copy of Petition Summary of Case Number 97 / PUU-XIV / 2016.

[17] Copy of the Constitutional Court Decision of the Republic of Indonesia Number 97 / PUU-XIV / 2016, p. 154. 